\title{
DAMPAK PERCERAIAN PADA PEREMPUAN USIA MUDA DI KECAMATAN PONDOK TINGGI KOTA SUNGAI PENUH
}

\author{
Santi Muardini, Alia Azmi, Fatmariza \\ Prodi Pendidikan Pancasila dan Kewarganegaraan \\ Universitas Negeri Padang \\ E-Mail: santimuardini99@gmail.com
}

\begin{abstract}
This article is in the background because the level of divorce that occurred in Sungai Penuh City has increased every year, especially in Pondok Tinggi District. Where this article aims to analyze the impact of divorce on young women on socio-economic conditions and social-community conditions in Pondok Tinggi District. This article was analyzed using descriptive qualitative methods conducted in Pondok Tinggi District, Sungai Penuh City, with research informants determined using purposive sampling. In the results of the study it was found that the impact of divorce on socio-economic conditions was the difficulty of young widows in fulfilling economic needs and family participation in helping to meet the economic needs of young widows namely parents of young widows. While divorce has an impact on social conditions on the stigma of young widows that divorce is the best decision for the survival of themselves and children because of problems that cannot be resolved again and negative views from the community that young widows have the potential to destroy the household because of the manner of dressing that is not polite. So that it is expected that women who decide to get married at a young age to maintain the integrity of their household should not divorce at a young age because it harms the woman herself where she must work to meet the needs of herself and her children.
\end{abstract}

\section{Keywords: Impact of Divorce, Young Age}

\begin{abstract}
Abstrak
Artikel ini di latar belakangi karena tingkat percerain yang terjadi di Kota Sungai Penuh mengalami peningkatan setiap tahunnya terutama yang terjadi di Kecamatan Pondok Tinggi. Dimana artikel ini bertujuan untuk menganalisis dampak perceraian pada perempuan usia muda terhadap kondisi sosial-ekonomi dan kondisi sosial-kemasyarakatan di Kecamatan Pondok Tinggi. Artikel ini di analisis menggunakan metode kualitatif deskriptif yang dilakukan di Kecamatan Pondok Tinggi Kota Sungai Penuh, dengan informan penelitian ditentukan menggunakan purposive sampling. Pada hasil penelitian ditemukan bahwa dampak perceraian terhadap kondisi sosial-ekonomi yaitu kesulitan janda muda dalam memenuhi kebutuhan ekonomi dan peran serta keluarga dalam membantu memenuhi kebutuhan ekonomi janda muda yaitu orang tua
\end{abstract}


janda muda. Sedangkan perceraian memberi dampak terhadap kondisi sosial-kemasyarakatan pada stigma janda muda bahwa perceraian adalah keputusan yang terbaik demi kelangsungan hidup diri sendiri dan anak karena permasalahan rumah tangga yang sudah tidak bisa diselesaikan lagi serta pandangan negatif dari masyarakat bahwa janda muda berpotensi sebagai perusak rumah tangga orang karena cara berpakaian yang kurang sopan. Sehingga diharapkan kepada para perempuan yang memutuskan menikah pada usia muda supaya menjaga keutuhan rumah tangganya jangan sampai bercerai di usia muda karena merugikan perempuan itu sendiri dimana dia harus bekerja demi memenuhi kebutuhan hidup diri sendiri dan anak.

\section{Kata Kunci: Dampak Perceraian, Usia Muda}

\section{PENDAHULUAN}

Pada saat sekarang ini terjadi peningkatan dalam pelaksanaan pernikahan terutama pada pasangan yang berusia muda. Dimana akibat dari pernikahan tersebut adalah terjadi perceraian pada pasangan usia muda karena tidak mampu untuk mengatasi permasalahan-permasalahan yang ada didalam rumah tangga sehingga menimbulkan dampak terhadap kondisi social-ekonomi dan kondisi social-kemasyarakatan pasangan usia muda terutama terhadap kehidupan mantan istri ( janda muda ).

Hal serupa juga diutarakan oleh beberapa penelitian terdahulu dari (Nina Soraya, 2013 ) menyatakan bahwa kehidupan perempuan usia muda setelah terjadi perceraian dia harus bisa memenuhi kebutuhan hidup diri sendiri dan anak dengan bekerja serta mereka juga harus menerima segala pembicaraan masyarakat tentang mereka yang sudah mendapatkan status sebagai seorang janda. Hal serupa dinyatakan oleh (Diana Lusyanti, 2014) menyatakan bahwa perceraian adalah jalan keluar yang terbaik atas permasalahan yang dihadapi. Selanjutnya (Andi Raihan,2014) menyatakan bahwa dasar pertimbangan Hakim Pengadilan Agama dalam memberikan putusan perkara cerai gugat. Sedangkan (Ahmad Ali Imron,2008) menyatakan bahwa setelah terjadi perceraian mantan istri (janda) harus bekerja untuk memenuhi kebutuhan hidup karena sudah tidak ada lagi kepala keluarga yang memenuhi kebutuhan hidup. Serta (Gunawan,2014) menyatakan bahwa percaraian akan membuat pasangan yang mengalami perceraian menjadi kesepian karena tidak adanya tempat untuk mencurahkan segala permasalahan yang dialami.

Adapun perbedaan penelitian ini dengan penelitian terdahulu adalah didalam penelitian ini penulis hanya mengemukakan dampak perceraian 
terhadap kondisi social-ekonomi dan kondisi social-kemasyarakatan. Sedangkan penelitian sebelum nya menjelaskan tentang kehidupan yang dialami janda lebih kesepian karena tidak lagi memiliki pasangan serta dia juga harus bisa bekerja demi memenuhi kebutuhan hidupnya. Berdasarkan data yang diperoleh dari Pengadilan Agama Sungai Penuh bahwa tingkat perceraian mengalami peningkatan setiap tahunnya terutama yang terjadi di Kecamatan Pondok Tinggi Kota Sungai Penuh dengan rincian data sebagai berikut:

Data Perceraian Penduduk Di Pengadilan Agama Sungai Penuh Tahun 2015-2017 Berdasarkan Daerah Tempat Tinggal

\begin{tabular}{|c|l|c|c|c|}
\hline \multirow{2}{*}{ No } & \multirow{2}{*}{ Kecamatan } & \multicolumn{3}{|c|}{ Tahun } \\
\cline { 3 - 5 } & & 2015 & 2016 & 2017 \\
\hline 1. & Pondok Tinggi & 50 & 50 & 184 \\
\hline 2. & Pesisir Bukit & 19 & 23 & 94 \\
\hline 3. & Kayu Aro & 68 & 68 & 150 \\
\hline 4. & Kayu Aro Barat & 21 & 156 & 134 \\
\hline 5. & Air Hangat & 93 & 112 & 64 \\
\hline & Jumlah Perceraian & 251 & 409 & 626 \\
\hline
\end{tabular}

Sumber: Pengadilan Agama Sungai Penuh Tahun 2017

Keterbatasan solusi yang pernah ada yaitu tidak kebanyakan orang atau peneliti yang memberikan solusi bahwa perlu adanya pendekatan terhadap janda muda berupa sosialisasi pekerjaan yang bisa dilakukan para perempuan yang menjadi seorang janda selain dari pekerjaan yang berkaitan dengan pekerjaan fisik serta memberikan pemahaman kepada masyarakat bahwa status janda bukanlah suatu hal yang selalu dianggap buruk. Padahal peran masyarakat disini harus lebih bijaksana lagi agar para janda tidak merasa menjadi orang yang terasing ditengah-tengah lingkungan masyarakat.

Kelebihan solusi yang ditawarkan dalam artikel penelitian ini adalah peneliti melibatkan semua pihak untuk ikut serta memberikan upaya terhadap dampak perceraian pada perempuan usia muda tersebut. Yakni petugas Pengadilan Agama, KUA,Masyarakat,Tokoh Masyarakat, dan Pemerintah agar juga ikut serta dalam memberikan solusi supaya tingkat perceraian pada pasangan usia muda dapat dikurangi.

Adapun tujuan penulisan artikel ini adalah untuk mengetahui dampak perceraian pada perempuan usia muda terhadap kondisi socialekonomi dan dampak perceraian pada perempuan usia muda terhadap kondisi social-kemasyarakatan di Kecamatan Pondok Tinggi Kota Sungai Penuh. Serta bertujuan untuk mengimplementasikan ilmu-ilmu yang didapatkan saat perkuliahan Pengantar Sosiologi dan Hukum Perdata. 
Serta untuk mengatasi tingkat perceraian yang mengalami peningkatan sebagai masukan kepada pemerintahan untuk menekan angka perceraian yang terjadi khususnya pasangan yang berusia muda.

\section{METODE PENELITIAN}

Metode penelitian ini adalah penelitian kualitatif sifatnya deskriptif atau menggambarkan suatu fenomena tertentu. Menurut Boghdan dan Tailor (LexyJ. Moleong 2002:3) metode kualitatif sebagai prosedur penelitian yang menghasilkan data deskriptif berupa kata-kata tertulis atau lisan dari orang- orang atau perilaku yang diamati. Untuk itu data informan penelitian dilakukan menggunakan teknik purposive sampling dengan informan penelitian janda muda dan keluarga janda muda. Lokasi penelitian dilakukan di Kecamatan Pondok Tinggi, Kota Sungai Penuh dengan waktu penelitian selama 1 bulan.

\section{HASIL DAN PEMBAHASAN}

Penelitian dilakukan terhadap janda yang melakukan pernikahan selama 4-8 tahun. Rentang waktu pernikahan yang relatif singkat memberi dampak pada munculnya stigma negatif dari janda sendiri terhadap status mereka. Selain hal tersebut, berikut ditemukan dampak perceraian yaitu:

1. Dampak Perceraian Pada Perempuan Usia Muda Terhadap Kondisi Sosial-Ekonomi

a. Cara janda muda dalam memenuhi kebutuhan ekonomi

Setelah terjadinya perceraian ini berdampak terhadap kehidupan sosial-ekonomi pasangan yang menikah pada usia muda khususnya janda. Strategi yang dilakukan janda muda demi mengoptimalkan perekonomian keluarga yaitu pertama,kembali kerumah orang tua, kedua, menambah sumber pendapatan ( dalam Firdaus,dkk 2016 ). Berdasarkan hasil temuan yang peneliti dapatkan dilapangan terlihat bahwa janda muda harus bekerja untuk memenuhi kebutuhan hidup diri sendiri dan anak.

b. Peran serta keluarga dalam membantu kebutuhan hidup janda muda

Pilihan tinggal dirumah orang tua karena faktor ekonomi yang susah dan tidak ada lagi kepala keluarga yang mencari nafkah. Mereka kembali kerumah orang tua bukan dikarenakan biaya sewa rumah tetapi mereka juga membutuhkan orang tuanya dengan alasan anaknya masih ada yang kecil dan tidak mungkin ditinggalkan sendirian disaat janda muda itu bekerja. Janda muda juga membutuhkan orang tua mereka karena dengan bantuan orang tua mereka janda muda bisa melakukan 
aktifitas yang mana mereka bekerja sebagai pekerjaan utama dari janda muda sebagai penyadap karet dan pekerjaan sampingan janda muda seperti batobo,mangarih,mencari kayu api,mencari pinang dan langkitang (dalam Firdaus,dkk 2016).

Berdasarkan hasil temuan yang peneliti dapatkan dilapangan terlihat bahwa yang membantu dalam memenuhi kebutuhan ekonomi janda muda adalah orang tua janda muda.

\section{c. Dampak Perceraian Pada Perempuan Usia Muda Terhadap Kondisi Sosial-Kemasyarakatan}

a. Pandangan janda muda terhadap dirinya sendiri

Hurlock ( dalam Listya Karvistina 2011 ) mengemukakan bahwa konsep diri merupakan gambaran mental yang dimiliki seseorang tentang dirinya yang mencakup citra fisik dan psikologis. Menurut Budi Anna Keliat (dalam Listya Karvistina 2011), konsep diri adalah semua ide,kepercayaan,dan pendirian yang diketahui individu tentang dirinya dan mempengaruhi dalam berhubungan dengan orang lain. Konsep diri menurut Colhooun dan Acocella (dalam Listya Karvistina 2011), terdiri dari konsep diri positif dan konsep diri negative. Individu yang memiliki konsep diri positif adalah individu yang tau betul tentang dirinya,sehingga evaluasi terhadap dirinya sendiri menjadi positif dan dapat menerima keberadaan orang lain . Konsep diri negatif adalah individu memandang tentang dirinya benar-benar tidak teratur, tidak memiliki kestabilan dan keutuhan diri.

Berdasarkan temuan yang peniliti dapatkan dilapangan terlihat bahwa dampak perceraian pada perempuan usia muda terhadap kondisi sosial-kemasyarakatan adalah pandangan janda muda terhadap dirinya sendiri, hal ini terbukti dengan adanya pengakuan dari janda muda bahwa dengan terjadinya perceraian dan status janda muda yang disandang saat ini membuat mereka malu karena dipandang negatif oleh masyarakat di sekitar lingkungan tempat tinggal. Tetapi, keputusan yang diambil adalah yang terbaik demi kelangsungan masa depan diri sendiri dan sang anak.

b. Pandangan keluarga janda muda terhadap dirinya

Seorang janda membutuhkan dukungan sosial yang berasal dari keluarga, teman,tetangga,maupun rekan kerja. Menurut Sarafino (1994) dalam Isra.M (2017),dukungan sosial adalah kenyamanan, perhatian, penghargaan,maupun bantuan dalam bentuk lainnya yang diterimanya dari individu dari orang lain ataupun dari kelompok. Ada lima bentuk dukungan sosial 
yang dapat diterima oleh individu yaitu dukungan emosional, penghargaan, intrumental, informasi, dan dukungan kelompok.

Kebohongan yang dilakukan oleh sang suami dimana tidak ada kejujuran bahwa dia adalah seorang pemakai narkoba serta dia juga sepakat bersama anggota keluarga nya untuk merahasiakan hal tersebut dari pihak keluarga perempuan selama berumah tangga ( Jurnal Perempuan, 2018).

Berdasarkan temuan yang peneliti dapatkan dilapangan terlihat bahwa pandangan keluarga janda muda terhadap dirinya adalah adanya persetujuan dari pihak keluarga agar dilakukan perceraian antara anak mereka dengan sang suami. Hal ini dilakukan karena terdapat permasalahan yang terjadi didalam rumah tangga yang sudah tidak bisa diselesaikan lagi dan kebohongan yang dilakukan oleh menantu terhadap anak dan keluarga kami serta kesanggupan orang tua menerima sang anak untuk kembali tinggal bersama mereka setelah terjadinya perceraian walaupun dengan kondisi kehidupan yang serba kekurangan juga.

c. Pandangan masyarakat terhadap janda muda

Banyaknya janda dan struktur masyarakat, serta dasar pemikiran masyarakat yang berbeda menyebabkan persepsi negatif masyarakat terhadap janda yaitu Status janda dalam masyarakat masih dipandang sebagai hal yang negatif dan selalu mendapat sorotan,serta perlu mendapat perhatian lebih dari masyarakat.

Anggapan bahwa janda adalah perusak hubungan orang, terutama hubungan suami istri masih ada ditengah masyarakat. Masyarakat menganggap bahwa apa yang dilakukan oleh janda tersebut adalah sesuatu yang dinilai masyarakat tidak baik hal tersebut menunjukkan bahwa masih terdapat anomie atau keterputusan hubungan antara norma kultural dan tujuan masyarakat yang terstruktur secara sosial dari anggota masyarakat untuk bertindak sesuai dengan nilai kultural. Hal tersebut dikarenakan ada warga yang ( janda ) yang melakukan suatu hal yang melanggar norma atau dirasa telah melakukan hal-hal yang tidak baik menurut penilaian masyarakat ( dalam Listya Karvistina 2011 ).

Berdasarkan temuan yang peneliti dapatkan dilapangan terlihat bahwa masyarakat berpandangan terhadap janda berpotensi sebagai perusak rumah tangga walaupun tidak semua janda yang melakukan ini tetapi sebagian janda berpotensi melakukan ini. Hal ini dibuktikan dengan adanya perilaku sebagian janda yang tidak sesuai seperti gaya 
berpakaian janda yang terlihat seksi dan cara pergaulan dari sebagian janda yang terindikasi menjadi seorang wanita malam.

d. Pandangan tokoh masyarakat terhadap janda muda

Status janda merupakan suatu kelompok masyarakat yang didasarkan pada suatu perpisahan atau kesendirian yang dialami oleh seorang perempuan atau istri, mengenai gaya hiup dimana berusaha memenuhi kebutuhan untuk menyambung hidup setelah ditinggal oleh suami baik karena meninggal, cerai, maupun ditinggal pergi begitu saja dan kehormatan yang diberikan kepada mereka oleh orang lain atau masyarakat (Weber,1946:225) dalam Listya Karvistina (2011). Apapun status dan bagaimana tingkat perekonomian masyarakat, tokoh masyarakat tetap memandang anggota masyarakatnya sama. Tokoh masyarakat cenderung berempati dan menilai setiap anggota masyarakat melalui sikap atau perilaku sehari-hari terutama dalam hal ini adalah kaum janda. Dalam Listya Karvistina (2011).

Berdasarkan hasil temuan yang peneliti dapatkan dilapangan terlihat bahwa bahwa tokoh masyarakat sangat menyayangkan apabila terjadinya perceraian maka dari itu, untuk menghindari ini khususnya bagi pasangan yang akan menikah muda sebaiknya memikirkan terlebih dahulu mengenai kematangan emosional maupun kesiapan finansial sebelum menikah. Hal ini ditujukan untuk menghindari terjadinya perceraian.

e. Pandangan pemerintah terhadap janda muda

Menurut hakim yang menangani kasus perceraian akibat menikah usia muda rata-rata alasan pengajuan mereka yaitu:

1. Suami tidak bertanggung jawab, baik lahir maupun batin istri terutama dalam kebutuhan ekonomi. Kehidupan rumah tangga sulit dipertahankan jika berhubungan dengan ketidakmampuan suami dalam membiayai kehidupan keluarganya. Suami yang tidak punya penghasilan tetap akan sulit menafkahi istri dan anaknya.

2. Suami atau istri mudah tersinggung. Pemikiran yang belum cukup dewasa sangat mudah mengalami pertikaian. Serta sering terjadinya kesalah pahaman antara suami-istri karena tidak didasari rasa hormat menghormati dan saling menyayangi.

3. Kepribadian anak yang masih labil. Anak-anak yang menikah di usia muda tentunya kurang menikmati masa remaja mereka. Di usia tersebut rata-rata anak pada 
umumnya sibuk dengan dunia pendidikan,bercengkrama dengan teman sejawatnya atau berpergian ketempat-tempat yang menarik bersama teman-temannya. Namun jika sang anak telah menikah mereka harus berhadapan dengan urusan rumah tangga. Sehingga terkadang anak sulit mengontrol emosi sendiri ketika bergelut dengan urusan rumah tangga,maka hal ini menjadi salah satu penyebab seringnya terjadi pertikaian didalam rumah tangga. Dalam (Ummu Kalsum 2017)

Berdasarkan hasil temuan yang peneliti dapatkan terlihat bahwa pemerintah sangat menyayangkan terjadinya perceraian khususnya pasangan yang berusia muda karena perceraian ini berdampak pada kondisi sosial-ekonomi keduanya. Hal ini juga berdampak terhadap kelangsungan masa depan pasangan muda yang secara tidak langsung telah menjadi hambatan dimana mereka yang seharusnya masih bisa mendapatkan pendidikan yang tinggi karena pernikahan pada usia muda yang mereka lakukan dan berakhir dengan perceraian ".

f. Pandangan mantan suami terhadap mantan istri (janda muda)

Adanya ketidaksesuaian pendapat dalam rumah tangga. Menurut Naqiyah (2007) dalam Armansyah (2014) mengatakan dengan tegas bahwa: " Hal yang ditengarahi menjadi polemik yang memicu keretakan rumah tangga adalah tidak adanya kecerdasan emosi dalam memahami perasaan pasangan". Apabila dalam keluarga tidak ada terdapat persesuaian pendapat antara sesama anggotanya maka ketentraman, kebahagiaan, keserasian, kasihsayang, kehangatan, kemesraan sukar didapat dalam keluarga. Maria (1998:39) dalam Armansyah (2014) mengatakan bahwa: Hakekatnya perkawinan merupakan " integrasi " proses penyesuain dua insan yang berlangsung terus menerus selama perkawinan itu sendiri. Dalam proses integrasi itu sendiri biasanya mengalami berbagai hambatan yang bersifat fisik atau mental/emosional, yang menyatakan diri dalam bentuk benturan-benturan pendapat,sikap,atau tingkah laku antara suami-istri yang menimbulkan rasa kesal, marah, benci, curiga, dan sebel yang terkadang mengakibatkan terjadinya suatu malapetaka besar “ perceraian ".

Berdasarkan hasil temuan yang peneliti dapatkan dilapangan bahwa perceraian yang terjadi karena adanya kesepakatan bersama antara kedua belah pihak dan mantan 
suami mengakui kesalahan yang telah dilakukannya walaupun mantan istri tidak bisa menerima dan harus berakhir dengan perceraian.

g. Pandangan laki-laki yang masih lajang terhadap janda muda

Mathis (2005) dalam Listya Karvistina 2011, menemukan bahwa sikap orang tua terhadap perceraian mempengaruhi sikap anak-anak terhadap perceraian. Saat sikap orang tua terhadap perceraian itu lebih positif maka sikap anak dewasa awal terhadap perceraian juga lebih positif. Seorang anak dapat meniru sikap orang tuanya,orang-orang disekitar atau bahkan informasi yang dilihat dari media.Rendahya dukungan remaja baik laki-laki maupun perempuan terhadap perceraian merupakan suatu hal yang positif dan mendukung pandangan mengenai pentingnya menjaga keutuhan keluarga. Namun demikian, masa remaja identik dengan masa berpacaran dan berpasangan. Dengan demikian pemahaman remaja akan perkawinan dan perceraian mungkin masih indah. Umumnya remaja belum memikirkan secara mendalam tentang persoalanpersoalan dalam perkawinan seperti perbedaan prinsip,agama,atau keyakinan,dan budaya. Remaja meyakini bahwa cinta cukup untuk mengatasi masalah dalam perkawinan (Dariyo,2008) dalam Listya Karvistina 2011.

Berdasarkan hasil temuan yang peneliti dapatkan dilapangan terdapat sedikit perbedaan dimana pada tempat penelitian ditemukan bahwa pandangan laki-laki yang masih lajang terhadap janda adalah negatif karena cara bergaul dan cara berpakaian janda yang kurang sopan ditengah-tengah masyarakat. Tetapi dilihat dari setuju atau tidaknya laki-laki yang masih lajang terhadap perceraian yang terjadi pada usia muda mereka mengatakan tidak setuju.

\section{PENUTUP}

Berdasarkan temuan penelitian dan pembahasan yang telah dilakukan dapat disimpulkan bahwa dampak perceraian pada perempuan usia muda terhadap kondisi social ekonomi adalah janda muda harus bekerja untuk memenuhi kebutuhan hidup diri sendiri dan anak serta adanya bantuan dari orang tua untuk menanmbah dalam memenuhi kebutuhan hidup janda muda serta dampak perceraian pada perempuan usia muda terhadap kondisi social-kemasyarakatan adalah adanya pandangan dari masyarakat bahwa janda muda berpotensi sebagai perusak hubungan rumah tangga orang lain dan cara berpakaian janda yang dianggap kurang sopan. 
Peneliti telah menekuni bidang ilmu yang sesuai dengan penelitian ini diantaranya bidang ilmu Pengantar Sosiologi yang dimana bidang ilmu ini membahas secara keseluruhan seluk beluk kehidupan masyarakat. Serta bidang ilmu Hukum Perdata yang membahas tentang perkawinan.

Impilikasi dari penelitian ini terhadap penelitian berikutnya adalah penelitian berikutnya dapat dengan mudah menangani serta memahami tentang dampak perceraian pada perempuan terutama yang berusia muda serta kegiatan-kegiatan ekonomi yang bisa dilakukann untuk menunjang kehidupan para janda setelah terjadi perceraian seperti dengan mengadakan kegiatan PKK untuk menambah pemasukan para janda.

Berdasarkan kesimpulan-kesimpulan yang diambil berkaitan dengan penelitian ini maka penulis menyampaikan saran yang kiranya dapat dilakukan dan bermanfaat bagi orang lain diantaranya bagi:

a. Bagi Pengadilan Agama Kota Sungai Penuh

Dapat memberikan pemahaman kepada masyarakat tentang dampak yang akan ditimbulkan setelah terjadinya perceraian terutama perceraian yang dilakukan oleh penduduk yang berusia muda. Dimana dampak yang akan dirasakan bukan hanya terhadap diri sendiri tetapi juga terhadap anak dan keluarga pasangan suami-istri yang bercerai. Sehingga dengan adanya penelitian ini diharapkan tingkat perceraian yang terjadi di Kota Sungai Penuh dapat mengalami penurunan untuk tahun-tahun berikutnya dibandingkan dengan yang terjadi saat ini.

b. Bagi Pasangan Usia Muda Yang Bercerai

Dapat memberikan pemahaman kepada pasangan suamiistri yang berusia muda bahwa pernikahan bukan hanya untuk mencari kebahagiaan sementara atas nama cinta tetapi mereka juga harus paham tentang bagaimana cara menjalani kehidupan rumah tangga yang baik sesuai dengan yang di harapkan agar perceraian pada pasangan suami-istri yang berusia muda tidak meningkat.

c. Bagi Keluarga Pasangan Suami-Istri Yang Bercerai Pada Usia Muda

Dapat memberikan pamahan kepada orang tua pasangan suami-istri yang berusia muda bahwa untuk melangsungkan suatu pernikahan bagi anak mereka butuh berbagai persiapan bukan hanya dari segi materi tetapi mental sang anak harus siap untuk menjalani kehidupan rumah tangga karena didalam kehidupan rumah tangga yang akan dijalani nanti oleh sang anak bukan hanya memikirkan kehidupan saat ini saja tetapi untuk kelangsungan hidup dimasa depan. 
Sehingga tidak terjadi perceraian di usia muda yang nantinya akan berpengaruh kepada kehidupan si anak kedepannya.

Ucapan Terima Kasih

Rasa terima kasih yang sedalam-dalam nya peneliti sampaikan kepada para informan yang telah memberikan informasi untuk melengkapi data penelitian yang peneliti lakukan sehingga penelitian ini dapat berjalan dengan baik dan sesuai harapan peneliti semoga apa yang peneliti tulis didalam artikel ini bermanfaat bagi para pembaca serta peneliti dan para informan mendapatkan balasan pahala dari Allah Swt.

\section{DAFTAR KEPUSTAKAAN}

\section{$\underline{\text { Skripsi }}$}

Nina Soraya 2013. Perceraian Wanita Usia Muda: Studi terhadap Perilaku Sosial Wanita Muda Pasca Perceraian Di Kecamatan Mojoroto Kota Kediri. Universitas Islam Negeri Maulana Malik Ibrahim Malang

Diana Lusyanti (1110111000013) 2014. Pernikahan dan Perceraian di masyarakat: Studi Terhadap Penyebab Perceraian Di Masyarakat Ragamukti, Tajurhalang

\section{Jurnal:}

Akhirudin.2016.Dampak Pernikahan Usia Muda.Mahkamah.Vol. 1,No. 1. Hal 206-222

Indah Ahdiah.2013.Peran-Peran Perempuan Dalam Masyarakat.Jurnal Academica FISIP Untad.Vol. 05.No. 02. Hal 1086-1092

Nifki Setya Welly.2017.Makna Hidup Janda Muda Pelaku Cerai Gugat Di Kota Pekanbaru.JOM FISIP. Vol. 4.No. 2. Hal 1-13

Opi Andriani,dkk.2017. Gambaran Permasalahan Pasangan Muda Di Kabupaten Kerinci. Jurnal Konseling Indonesia. Vol. 03 No.1 Hal 1-8 Armansyah Matondang.2014. Faktor-Faktor Yang Mengakibatkan Perceraian Dalam Perkawinan

Nani Zulminarni. 2018. Perempuan dan Ekonomi Perawatan. Jurnal Perempuan. Vol. 23 No. 4 Hal 24-34

\section{Perundang-undangan:}

Undang-Undang No 1 Tahun 1974 tenntang Perkawinan. 